\title{
CLINICAL SAFETY OF ZAFIRLUKAST TREATMENT DURING A FOREIGN BODY INFLAMMATORY REACTION IN NILE TILAPIAS, OREOCHROMIS NILOTICUS
}

\section{Susana Luporini de Oliveira1, Mayumi Fernanda Aracati' ${ }^{1}$, Leticia Franchin Rodrigues' ${ }^{1}$, Camila Carlino da Costa1 ${ }^{1}$, Gabriel Conde ${ }^{1}$, Alessandra Cristina de Moraes ${ }^{2}$, Wilson Gomez Manrique ${ }^{2}$, Ives Charlie da Silva ${ }^{3}$ and Marco Antonio de Andrade Belo ${ }^{1,4^{*}}$}

\author{
${ }^{1}$ Department of Preventive Veterinary Medicine - São Paulo State University (UNESP), Jaboticabal/SP, Brazil \\ ${ }^{2}$ Department of Veterinary Medicine, Federal University of Rondônia (UNIR), Rolim de Moura/RO, Brazil \\ ${ }^{3}$ Department of Pharmacology, Institute of Biomedical Sciences, University of São Paulo (USP), São Paulo/SP, Brazil \\ ${ }^{4}$ Laboratory of Animal Pharmacology and Toxicology, Brasil University (UB), Descalvado/SP, Brazil
}

\section{ARTICLE INFO}

\section{Article History:}

Received $10^{\text {th }}$ March, 2021

Received in revised form

$27^{\text {th }}$ April, 2021

Accepted $08^{\text {th }}$ May, 2021

Published online $26^{\text {th }}$ June, 2021

Key Words:

Cichlids, Chronic Inflammation,

Antagonism,

Cysteine Leukotrienes.

*Corresponding author:

Marco Antonio de Andrade Belo,

\begin{abstract}
Seeking to understand the defense mechanisms of tilapia to assist in the sanitary management of fish farms, this study aimed to evaluate the clinical safety of Nile tilapia (Oreochromis niloticus) submitted to oral treatment with $500 \mu \mathrm{g}$ of zafirlukast $/ \mathrm{Kg}$ of body weight during chronic inflammation, through the implantation of round glass coverslips in the subcutaneous tissue. For this study, 63 male tilapiawere randomly distributed in 9 aquariums to compose the following treatments: Control submitted to inflammatory stimulus without treatment; CT - Conventional treatment; PT - Prolonged treatment. Seven animals were evaluated per treatment in three periods: 2, 4 and 8 days post-implantation (DPI).Tilapia during foreign body reaction showed a decrease in erythrocyte counts and hematocrit values, as well as macrocytic changes, these effects were mitigated by treatment with zafirlukast. Control tilapia showed a gradual increase over time in serum values of total protein, cholesterol, and triglycerides. Serum values of ALT, AST and alkaline phosphatase of control tilapia showed an increase in the late phase of the chronic inflammatory process $(8 \mathrm{DPI})$. Therefore, it was possible to conclude that tilapia treated with $500 \mu \mathrm{g}$ of zafirlukast showed attenuation of hematological changes resulting from fluid-electrolyte imbalance during a foreign body inflammation, as well as ameliorated serum biochemical disorders, demonstrating the clinical safety of oral treatment with this cys-leukotriene blocker.
\end{abstract}

Copyright (C) 2021, Susana Luporini de Oliveira et al. This is an open access article distributed under the Creative Commons Attribution License, which permits unrestricted use, distribution, and reproduction in any medium, provided the original work is properly cited.

Citation: Susana Luporini de Oliveira, Mayumi Fernanda Aracati, Leticia Franchin Rodrigues, Camila Carlino da Costa, Gabriel Conde, Alessandra Cristina de Moraes, Wilson Gomez Manrique, Ives Charlie da Silva and Marco Antonio de Andrade Belo. "Performance of Pervious Concrete under Shear and Bearing strengths ", International Journal of Development Research, 11, (06), 47914-47919.

\section{INTRODUCTION}

According to SOFIA report (FAO, 2020), aquaculture production is essential for the growth of the global economy, and Brazil has enormous potential to be explored, reaching production of 758,006 tons in 2019. In intensive fish production, when outbreaks of infectious diseases occur, one of the alternatives for treatment is chemotherapy drugs during sanitary management. However, there are few drugs registered for use in fish, a fact that results in the indiscriminate use of various compounds in aquaculture (Aracati et al., 2021). For this reason, the study of clinical safety in fish becomes relevant, and this happens through hematological and biochemical tests, which are essential parameters to assess the physiological condition of fish (Mahmoud et al., 2018) against the use of pharmaceutical molecules in fish farms. Fish have a variety of specific and non-specific defense mechanisms against invading organisms (Prado et al., 2018, Moraes et al., 2018; Rodrigues-Soares et al., 2018). Inflammation in teleost fish can effectively reproduce the inflammatory process in mammals, demonstrating that signaling and gene expression pathways are well conserved throughout evolution (Manrique et al., 2015; Forn-Cuní et al., 2017; Manrique et al., 2017). These protection mechanisms are fundamental for fish, and consist of controlled and coordinated processes, seeking to minimize tissue damage and restore normal physiological conditions (Kim et al., 2007; Charlie-Silva et al., 2019). Pathophysiological studies of the foreign body type reaction in fish have become extremely relevant in aquaculture (Charlie-Silva et al., 2020), as it can help in the 
development of therapeutic and vaccine strategies. The implantation of glass coverslips in the subcutaneous tissue of fish represents a classic model for studying chronic inflammation, resulting in macrophage accumulation and giant cell formation (Belo et al., 2014; Petrillo et al., 2017). The accumulation of these inflammatory cells derived from monocytes present in the bloodstream is evaluated as an important inflammatory event facing pathological processes (Belo et al., 2005; 2012a). Zafirlukast has anti-inflammatory activity by antagonizing the cysteine leukotriene receptors, CysLTR1, acting on smooth muscle contraction and preventing the increase in vascular permeability, thus reducing edema formation and diapedesis (Scott \& Peters-Golden, 2013), in addition to presenting secondary antiinflammatory activities, which appear to be particularly effective in targeting neutrophils and monocytes/macrophages (Scott \& PetersGolden, 2013). These and other secondary anti-inflammatory mechanisms of CysLTR1 antagonists have been studied in human medicine, but little is known about the blocking of this receptor and its effects in teleost fish. Inorder to understand the events and mechanisms present in the pathophysiology of chronic inflammation associated with lack of information on the clinical safety of zafirlukast in tilapia, this investigation studied the action of the cysleukotriene antagonist through hematological and biochemical analysis during the foreign body inflammatory reaction in Nile tilapia (Oreochromis niloticus).

\section{MATERIAL AND METHODS}

Fish: For this study, 63 male tilapia, belonging to the same spawn from the Aquabel farm (Porto Ferreira, São Paulo State, Brazil) were randomly distributed in 9 aquariums ( $100 \mathrm{~L}$ of water, $\mathrm{n}=7$ ) supplied with running water without chlorine from an artesian well with a recirculation system at a flow rate of $1 \mathrm{~L} / \mathrm{min}$. After being transported to the aquarium, the fish were acclimated for 15 days, the time necessary for the plasmatic concentration of cortisol and osmolarity to return for baseline levels. In the first three days of acclimatization, the animals were submitted to bath with $\mathrm{NaCl}$ solution at a concentration of $6.0 \mathrm{~g} / \mathrm{L}$ (Carneiro \& Urbinati, 2001). Fish were fed with $2 \%$ of the aquarium biomass with commercial food (LAGUNA ${ }^{\circledR}$ - ocial Company). The water quality parameters were determined twice a day during the entire experimental period using pHmeter YSI-63 and oximeterYSI-55, and their values remained within the appropriate range for the well-being of tropical fish (Boyd, 1990) (dissolved oxygen $=4.07 \pm 0.89 \mathrm{mg} \mathrm{L}^{-1}$; temperature $=27.64 \pm 2.05^{\circ} \mathrm{C} ; \mathrm{pH}=$ $7.64 \pm 0.54$; and conductivity $=208.29 \pm 97.57 \mu \mathrm{S} / \mathrm{cm}$ ). This research was approved by the Ethics Committee on the Use of Animals from Brazil University (UB), process number 00152016.

Experimental Design: Tilapia were randomly distributed in 9 aquariums ( $100 \mathrm{~L}$ of water, $\mathrm{n}=7$ ) to compose the following treatments: Control submitted to inflammatory stimulus without treatment with Zafirlukast; CT - Conventional treatment with oral administration of $500 \mu \mathrm{g}$ of Zafirlukast after inflammatory stimulus; PT - Prolonged treatment with oral administration of $500 \mu \mathrm{g}$ of Zafirlukast for one week before and continuously after the inflammatory stimulus. Seven animals were evaluated per treatment in three periods: 2, 4 and 8 dayspost-implantation (DPI) of the glass coverslip in the subcutaneous tissue.

Anti-inflammatory treatment: Tilapia were fed with commercial feed (LAGUNA $®$ - Social Company, containing $32 \%$ crude protein, $7 \%$, ethereal extract, $5 \%$ crude fiber and $12 \%$ mineral matter), and feeding was carried out twice a day (8:00 am and 5:00 pm), with administration of $2 \%$ of the aquarium biomass. Zafirlukast (Accolate; Astra Zeneca Laboratory, UK) at a dose of $500 \mu \mathrm{g} / \mathrm{kg}$ body weight was added to the diets from CT and PT treatments. To prepare the diets, the commercial feed was weighed in proportion to the average weight of tilapia from each tank and added $2 \%$ of vegetable oil plus the respective amount of zafirlukast $(500 \mu \mathrm{g})$ and stored in dark plastic bags, kept at $8^{\circ} \mathrm{C}$, until the moment of use. The diet of control animals without Zafirlukast was mixed with $2 \%$ vegetable oil to maintain the standardization of the nutritional balance.
Fish anestesia: Tilapias were anesthetized by immersion in an aqueous solution of benzocaine in the proportion of 1: 10,000 for bacterin inoculation in the swim bladder and 1: 500 at the time of euthanasia. Benzocaine was diluted in $98^{\circ}$ alcohol $(0.1 \mathrm{~g} / \mathrm{mL})$, completing the volume to $1 \mathrm{~L}$ (Wedemeyer, 1970). After experimental handling, the animals were replaced in the aquariums with continuous water flow and aeration.

Coverslip implant: Prior to implantation, the glass coverslips and the nylonthread for sutures were sterilized by autoclaving. Fish were anesthetized by immersion in a 1:10,000 (v:v) aqueous solution of benzocaine (Sigma Chemical Co., St. Louis, Missouri 63178, USA) for round glass coverslips implantation in the subcutaneous tissue, lateral-dorsal region caudal to the operculum (Sakabe et al., 2013). With a scalpel, the scales in the implant area were removed and an incision was realized. The subcutaneous tissue was divulged, and the coverslip was implanted between the skin and muscle tissue. Then the skin was sutured with simple stitches using nylon thread. After experimental handling, the animals were again placed in their respective aquariums with continuous water flow.

Hematological analysis: Seven fish per treatment (one aquarium for each treatment) were anesthetized to obtain three $\mathrm{mL}$ of blood samples through the caudal vessel at 2,4 and 8 days postimplantation (DPI), which were aliquoted in two sets: one using a heparin-coated (5000 IU) needle and syringe and other without anticoagulant to obtain plasma and serum samples, respectively. The blood count was performed using a hemocytometer (Neubauer chamber) and Natt and Herrick solution (1952) (ratio 1: $100 \mathrm{v}: \mathrm{v})$. The hematocrit was determined by the microhematocrit centrifugation technique and the hemoglobin concentration with Drabkin's reagent read at $540 \mathrm{~nm}$. Mean corpuscular volume (MCV)and mean corpuscular hemoglobin concentration (MCHC) were calculated from hematocrit, hemoglobin, and red blood cells (Farias et al., 2016).

Serum Biochemical Assessment: Blood samples from fish without anticoagulant were centrifuged at $10000 \mathrm{rpm}$ for $5 \mathrm{~min}$. at $4^{\circ} \mathrm{C}$ to obtain serum and determination of total protein, alkaline phosphatase (ALP), aspartate aminotransferase (AST), alanine aminotransferase (ALT), creatinine, albumin, cholesterol, triglycerides using a semiautomatic biochemical analyzer (Model LabQuest ${ }^{\circledR}$ - Bioplus Company) and fish glycemia was determined using the Accu-Chek Performa device.

Statistical analysis: The experimental design for clinical safety assessment (hematological and serum biochemical analysis) was completely randomized in a $3 \times 3$ factorial scheme (three treatments: $\mathrm{PT}, \mathrm{CT}$ and control $\mathrm{X}$ three evaluation periods: 2,4 and $8 \mathrm{DPI}$ ). Analyzes of variance to compare the different experimental groups were performed using the GLM (General Linear Model) procedure of the SAS program, version 9.3 (Statistical Analysis Software, 2012). Significant differences $(p<0.05)$ were estimated based on Tukey's test at the $95 \%$ confidence level.

\section{RESULTS}

Hematological analysis: Control tilapia showed a significant decrease $(\mathrm{p}<0.05)$ in the percentage values of hematocrit 2 DPI compared to zafirlukast treated fish (CT) (Table 1). Control fish showed a significant increase $(\mathrm{p}<0.05)$ in $\mathrm{MCV}$ when compared to fish treated with Zafirlukast (PT) (Table 1). The study of inflammatory reaction evolution over time revealed that control fish showed a significant decrease $(\mathrm{p}<0.05)$ in $\mathrm{HCMC}$ between the second and eighth days, as well as recovery in percentage values of hematocrit in the same period (Table1).

Biochemical analysis: The analysis of hepatic cytotoxicity in tilapias implanted with coverslip revealed that control fish showed a significant increase $(\mathrm{P}<0.05)$ in serum ALT enzymatic activity when compared to groups treated with zafirlukast (PT and CT) 8DPI (Table 2). 
Tabela 1. Means values and ANOVA ${ }^{1}$ observed in the blood analysis of tilapia post-implantation

\begin{tabular}{|c|c|c|c|c|c|c|c|}
\hline Period & Treatments $^{3}$ & $\begin{array}{c}\text { Hematocrit } \\
(\%)\end{array}$ & $\begin{array}{l}\text { Erythrocyte } \\
\left(10^{6} / \mathrm{mm}^{3}\right)\end{array}$ & $\begin{array}{c}\mathrm{MCV}^{5} \\
(\mathrm{fL})\end{array}$ & & $\begin{array}{c}\mathrm{MCHC}^{5} \\
(\mathrm{~g} / \mathrm{dL})\end{array}$ & $\begin{array}{c}\text { Hemoglobin } \\
(\mathrm{g} / \mathrm{dL})\end{array}$ \\
\hline \multirow{3}{*}{ 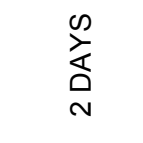 } & PT & $19.83 \pm 0.44 \mathrm{ABa}$ & $1.80 \pm 0.12 \mathrm{Aa}$ & $126.04 \pm 6.78$ & $\mathrm{Aa}$ & $23.16 \pm 2.96 \mathrm{Aab}$ & $5.05 \pm 0.53 \mathrm{Aa}$ \\
\hline & CT & $22.71 \pm 0.88$ Aab & $1.62 \pm 0.05 \mathrm{Aa}$ & $133.51 \pm 5.92$ & $\mathrm{Aa}$ & $20.99 \pm 0.41 \mathrm{Aa}$ & $4.60 \pm 0.28 \mathrm{Aa}$ \\
\hline & Control & $17.66 \pm 0.42 \mathrm{Bb}$ & $1.34 \pm 0.08 \mathrm{Aa}$ & $139.48 \pm 4.89$ & Aa & $23.62 \pm 1.01 \mathrm{Aa}$ & $4.32 \pm 0.18 \mathrm{Aa}$ \\
\hline \multirow{3}{*}{ 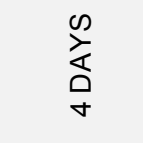 } & PT & $19.57 \pm 0.35 \mathrm{Aa}$ & $1.77 \pm 0.13 \mathrm{Aa}$ & $115.51 \pm 7.92$ & $\mathrm{Aa}$ & $25.44 \pm 0.89 \mathrm{Aa}$ & $5.00 \pm 0.25 \mathrm{Aa}$ \\
\hline & CT & $20.00 \pm 0.76 \mathrm{Ab}$ & $1.38 \pm 0.08 \mathrm{Aa}$ & $150.85 \pm 12.40$ & Aa & $24.74 \pm 0.51 \mathrm{Aa}$ & $4.80 \pm 0.10 \mathrm{Aa}$ \\
\hline & Control & $21.42 \pm 0.40$ Aab & $1.53 \pm 0.03 \mathrm{Aa}$ & $134.63 \pm 2.55$ & $\mathrm{Aa}$ & $23.39 \pm 0.70 \mathrm{Aa}$ & $5.00 \pm 0.13 \mathrm{Aa}$ \\
\hline \multirow{3}{*}{ 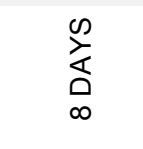 } & PT & $22.87 \pm 1.27 \mathrm{Aa}$ & $1.85 \pm 0.15^{\mathrm{Aa}}$ & $116.41 \pm 9.25$ & $\mathrm{Ba}$ & $16.81 \pm 0.25^{A b}$ & $4.11 \pm 0.38 \mathrm{Aa}$ \\
\hline & $\mathrm{CT}$ & $27.00 \pm 0.71 \mathrm{Aa}$ & $1.94 \pm 0.03 \mathrm{Aa}$ & $143.62 \pm 4.63$ & $\mathrm{ABa}$ & $19.86 \pm 0.52 \mathrm{Aa}$ & $5.33 \pm 0.12 \mathrm{Aa}$ \\
\hline & Control & $25.42 \pm 1.27 \mathrm{Aa}$ & $1.52 \pm 0.09 \mathrm{Aa}$ & $169.15 \pm 4.72$ & Aa & $15.73 \pm 0.80^{A b}$ & $3.95 \pm 0.19 \mathrm{Aa}$ \\
\hline \multicolumn{2}{|l|}{ Treatment } & 4.74 * & $6.15^{\text {** }}$ & $8.44^{* *}$ & & $0.37^{\mathrm{NS}}$ & $1.27^{\mathrm{NS}}$ \\
\hline \multicolumn{2}{|l|}{ Time } & 23.94 ** & $2.69^{N S}$ & $1.19^{\mathrm{NS}}$ & & 17.75 ** & $1.18^{\mathrm{NS}}$ \\
\hline \multicolumn{2}{|c|}{ Treatmente $X$ Time } & 3.15 * & $1.88^{\mathrm{NS}}$ & $2.21^{\text {NS }}$ & & $1.49^{\mathrm{NS}}$ & $2.04^{\text {NS }}$ \\
\hline \multicolumn{2}{|l|}{$\overline{C . V}{ }^{4}$} & 12.25 & 18.97 & 17.81 & & 18.53 & 21.08 \\
\hline
\end{tabular}

${ }^{1}$ Means ( $\mathrm{n}=7$ ) followed by the same letter do not differ by Tukey test $(\mathrm{P}<0.05)$.

${ }^{2}$ Analysis of statistical variance represented by capital letters compares in the column the different treatments within each experimental day, lowercase letters compare the evolution of each treatment on the different experimental days.

${ }^{3}$ Control- implemented and untreated fish; CT- Conventional Treatment with zafirlukast; PT- Prolonged treatment.

${ }^{4} \mathrm{CV}$ - Coefficient of Variation (\%); NS - Not significant; *significant for $\mathrm{P}<0.05$; **Significant for $\mathrm{P}<0.01$.

${ }^{5} \mathrm{MCV}$ - Mean corpuscular volume; HCMC - Mean corpuscular hemoglobin concentration.

Tabela2. Means values $\left( \pm\right.$ SD) and ANOVA ${ }^{1}$ observed in the biochemistry analysis of AST, ALT and Alkaline phosphatase of tilapia during foreign body reaction

\begin{tabular}{|c|c|c|c|c|c|c|c|}
\hline \multirow{4}{*}{$\begin{array}{l}\text { Period } \\
0 \\
\frac{\infty}{2} \\
\stackrel{c}{2} \\
\sim\end{array}$} & \multirow{2}{*}{$\begin{array}{c}\text { Treatments }^{3} \\
\text { PT }\end{array}$} & \multicolumn{2}{|l|}{$\begin{array}{l}\mathrm{AST}^{5} \\
(\mathrm{U} / \mathrm{L}) \\
\end{array}$} & \multicolumn{2}{|l|}{$\begin{array}{l}\mathrm{ALT}^{5} \\
(\mathrm{U} / \mathrm{L}) \\
\end{array}$} & \multicolumn{2}{|c|}{$\begin{array}{c}\text { Alkaline phosphatase } \\
(\mathrm{U} / \mathrm{L})\end{array}$} \\
\hline & & $69.00 \pm 7.45$ & Aa & $28.20 \pm 1.24$ & $\mathrm{Aa}$ & $19.57 \pm 2.88$ & $\mathrm{Aa}$ \\
\hline & CT & $87.00 \pm 23.43$ & $\mathrm{Aa}$ & $31.57 \pm 5.97$ & $\mathrm{Aa}$ & $20.71 \pm 2.04$ & $\mathrm{Aa}$ \\
\hline & Control & $35.66 \pm 7.35$ & $\mathrm{Aa}$ & $23.66 \pm 4.37$ & Ab & $18.28 \pm 2.47$ & $A b$ \\
\hline \multirow{3}{*}{ 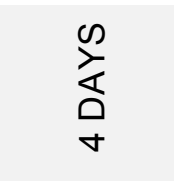 } & PT & $32.28 \pm 5.74$ & $\mathrm{Aa}$ & $13.33 \pm 0.84$ & $\mathrm{Aa}$ & $29.14 \pm 1.67$ & $\mathrm{Aa}$ \\
\hline & CT & $70.71 \pm 12.62$ & Aa & $18.50 \pm 1.32$ & $\mathrm{Aa}$ & $31.20 \pm 1.09$ & $\mathrm{Aa}$ \\
\hline & Control & $81.00 \pm 5.62$ & $\mathrm{Aa}$ & $29.42 \pm 2.67$ & Aab & $30,00 \pm 1.51$ & Aab \\
\hline \multirow{3}{*}{$\begin{array}{l}\infty \\
\frac{1}{0} \\
\infty\end{array}$} & PT & $57.12 \pm 11.10$ & $\mathrm{Aa}$ & $21.37 \pm 3.05$ & $\mathrm{Ba}$ & $29.50 \pm 2.65$ & $\mathrm{Aa}$ \\
\hline & $\mathrm{CT}$ & $89.25 \pm 12.75$ & $\mathrm{Aa}$ & $23.14 \pm 1.46$ & $\mathrm{Ba}$ & $28.37 \pm 1.93$ & $\mathrm{Aa}$ \\
\hline & Control & $115.14 \pm 26.84$ & $\mathrm{Aa}$ & $56.42 \pm 13.25$ & $\mathrm{Aa}$ & $30.28 \pm 2.04$ & $\mathrm{Aa}$ \\
\hline \multicolumn{2}{|l|}{ Treatments } & \multicolumn{2}{|l|}{$2.41^{\mathrm{NS}}$} & \multicolumn{2}{|l|}{4.32 * } & \multicolumn{2}{|l|}{$0.06^{\mathrm{NS}}$} \\
\hline \multicolumn{2}{|l|}{ Time } & \multicolumn{2}{|l|}{$2.01^{\mathrm{NS}}$} & \multicolumn{2}{|l|}{$2.97^{\text {NS }}$} & \multicolumn{2}{|l|}{14.92 ** } \\
\hline \multicolumn{2}{|c|}{ Treatment $X$ Time } & \multicolumn{2}{|l|}{$2.13^{\mathrm{NS}}$} & \multicolumn{2}{|l|}{2.98 * } & \multicolumn{2}{|l|}{$0.23^{\mathrm{NS}}$} \\
\hline \multicolumn{2}{|l|}{ C.V. ${ }^{4}$} & \multicolumn{2}{|l|}{66.05} & \multicolumn{2}{|l|}{62.67} & \multicolumn{2}{|l|}{26.49} \\
\hline
\end{tabular}

${ }^{1}$ Means $(\mathrm{n}=7)$ followed by the same letter do not differ by Tukey test $(\mathrm{P}<0.05)$;

${ }^{2}$ Analysis of statistical variance represented by capital letters compare in the column of different treatments within each experimental day, lowercase letters compare the evolution of each treatment on different experimental days;

${ }^{3}$ P.T. - prolonged treatment with zafirlukast; C.T. - Conventional treatment with zafirlukast; Control - implanted but not treated with zafirlukast;

${ }^{4}$ CV- Coefficient of Variation (\%); NS- Not significant; * - significant for $\mathrm{P}<0.05 ; * *$ - Significant for $\mathrm{P}<0.01$

${ }^{5}$ AST- A spartate aminotransferase; ALT- Alanine aminotransferase.

Tabela3. Means values $( \pm \mathrm{SD})$ and ANOVA1 observed in the biochemistry analysis of creatinine, total protein, cholesterol, triglycerides, albumin, and glucose of tilapia during foreign body reaction. 
Control fish showed a significant increase $(\mathrm{P}<0.05)$ in serum alkaline phosphatase and ALT values between periods 2 and 8 DPI, as well as a non-significant increase $(\mathrm{P}>0.05)$ in serum AST values (Table2). The serum biochemical study of renal and hepatic functionality showed an increase in blood creatinine values in the initialphase (2DPI) of the inflammatory reaction in all fish (Table 3), these findings were statistically significant $(\mathrm{p}<0.05)$ in tilapia treated with zafirlukast $(\mathrm{PT})$. Control fish showed a significant decrease $(\mathrm{p}<0.05)$ in serum total protein levels in the initial phase 2 DPI and recovery in the later phase 8 DPI. There were no significant variations $(p>0.05)$ in circulating values of total protein in fish treated with zafirlukast (Table 3). Control fish showed a significant increase in serum levels of cholesterol and triglycerides 8 DPI (Table 3), while treated fish did not show significant changes $(p>0.05)$ in serum values of these lipids. The blood glucose study did not reveal significant changes $(p>0.05)$ between the different treatments. However, increases in 4DPI blood glucose values are observed in animals treated with zafirlukast CT (Table 3).
Correlation analysis: Correlation analyzes between hematological and biochemical measurements in the CTtreatment revealed $69.37 \%$ $(\mathrm{p}=0.014$; Fig 1A) and $57.50 \%(\mathrm{p}=0.010$; Fig. 1B) significant negative correlations when comparing hemoglobin with creatinine and ALT, respectively. When hematocrit and creatinine were correlated, the control groups presented $-57.27 \%$ ( $p=0.010$; Fig 1C). However, the correlation between hematocrit and glucose showed a significant result $71.84 \%(\mathrm{p}=0.0004)$ for control group (Fig. 1D).

\section{DISCUSSION}

In the initial phase of inflammation, the hematological study of tilapia showed a decrease in red blood cell counts and hematocrit values in control fish, these effects were mitigated by treatment with zafirlukast. Changes in fluid-electrolyte balance may be due to stressful stimuli (Moonsen et al., 1999). Belo et al. (2014) observed in pacus during chronic inflammation a significant increase in the
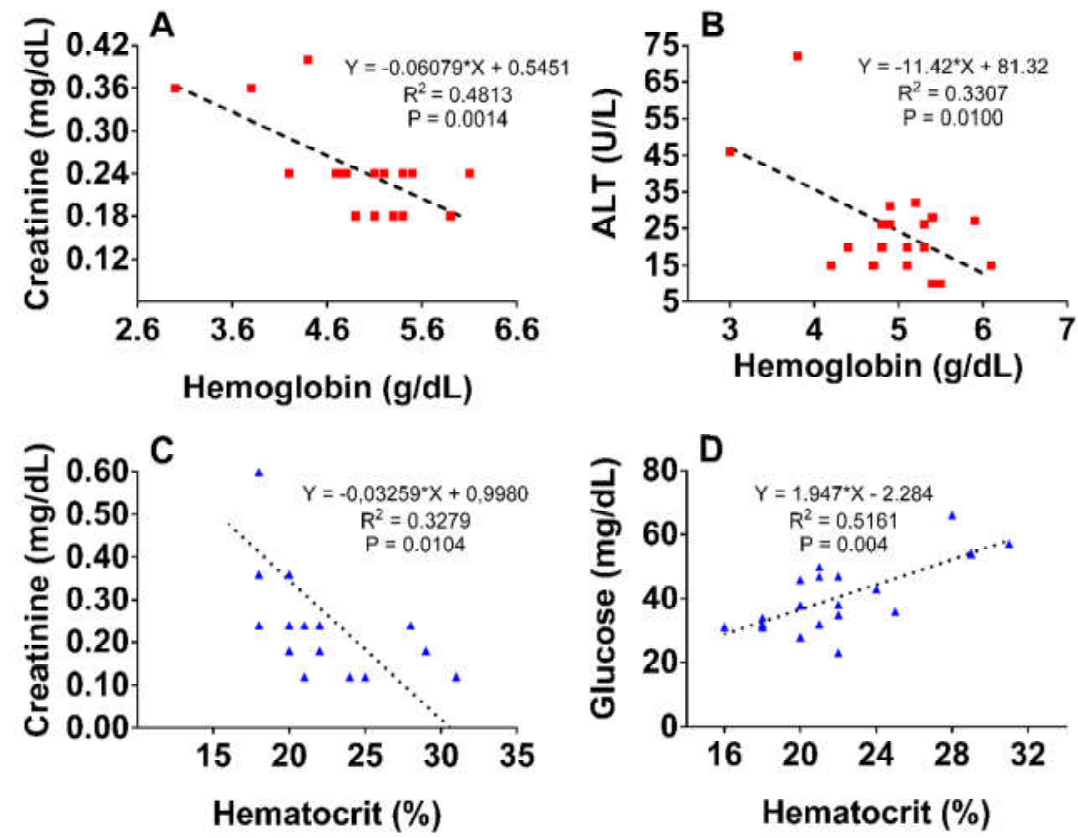

\section{PT (O) CT ( $\quad$ ) Control $(\Delta)$}

Figure 1. Correlation analysis between biochemical and hematological parameters of control animals, prolonged treatment (PT) and conventional treatment (CT) with $500 \mu \mathrm{g}$ zafirlukast

Tabela 4. Means values ( \pm SD) and ANOVA1 observed in the biochemistry analysis of creatinine, total protein, cholesterol, triglycerides, albumin, and glucose of tilapia during foreign body reaction

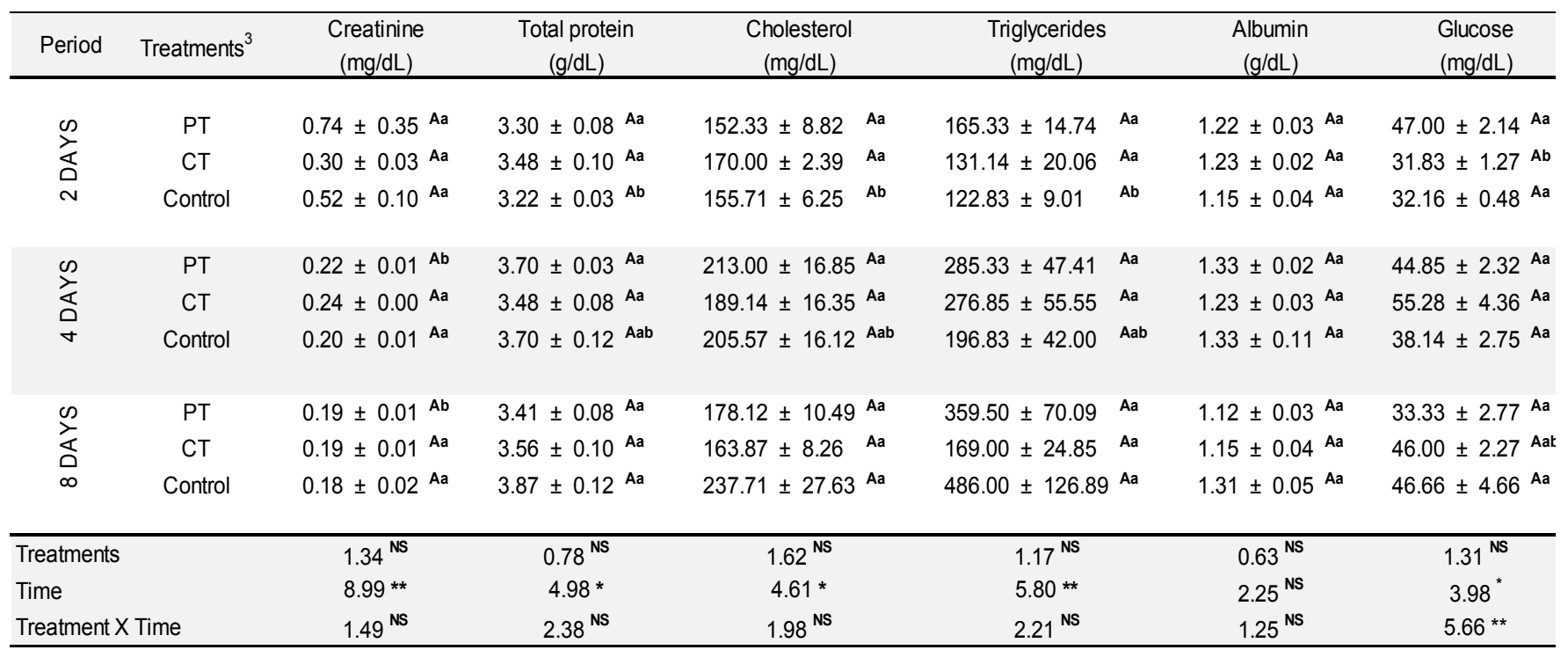


percentage values of hematocrit associated with high levels of circulating cortisol by high stocking density. According to these authors, endogenous cortisol present glucocorticoid and mineralocorticoid activity, such fact influence the fluid-electrolyte balance. With the evolution of the inflammatory reaction, tilapia showed macrocytic changes with a marked increase in the mean corpuscular volume of red blood cells, probably the fluid-electrolyte imbalance resulted in the influx of fluids into the intracellular compartment. These events were ameliorated by treatment with zafirlukast. On the other hand, Aracati et al. (2021) observed side effects of $500 \mu \mathrm{g}$ zafirlukast treatment in fish during acute aerocystitisby bacterins of Aeromonas hydrophila, characterized by microcytosis. The difference between both studies may be associated with the types of inflammatory stimulus between them, one evaluated in the acute phase by the presence of bacterial antigenic epitopes, and the other in the chronic phase associated to inert stimulus determined by the presence of the glass coverslip in the subcutaneous tissue.

Hematological and biochemical tests are essential parameters used as part of the assessment of fish health (Mahmoud et al., 2018). Several studies have demonstrated the hepatotoxicity of chronic treatments with zafirlukast (Reinus et al., 2000; Scheen, 2001; Marcy et al., 2004). Although serum biochemical values in the present study are within previously recorded reference ranges for tilapia under normal health conditions (Hrubec et al., 2000; Mauel et al., 2007). Control tilapia showed a gradual increase over time in serum values of total protein, alkaline phosphatase, cholesterol, triglycerides, and ALT in relation to animals treated with Zafirlukast. These findings suggest that the anti-inflammatory effect of this cis-leukotriene blocker attenuated the serum biochemical disturbances during the tilapia's foreign body type inflammatory reaction. The functionality of liver tissues can be determined by the concentration of substances synthesized in the liver or belonging to specific metabolic processes, such as albumin, urea, glucose, cholesterol, triglycerides, and others (Suja et al., 2004; Shih et al., 2005; Belo et al., 2012b). Serum values of ALT, AST and alkaline phosphatase of control tilapia showed an increase in the late phase of the chronic inflammatory process ( 8 DPI). These effects were mitigated by treatment with zafirlukast, corroborating the findings of El-Dessouki et al. (2018) who used tamoxifen to induce liver damage aiming to investigate the hepatoprotective effects of Zafirlukast in female Wistar rats for 10 days. These authors observed a significant decrease in plasma ALT activity compared to the control group, demonstrating the hepatoprotective effect of this anti-inflammatory. Furthermore, these authors highlighted antioxidant effects associated with treatment with this Cys-leukotriene antagonist. On the other hand, Reinus et al. (2000) and Actis et al. (2001) reported severe liver alterations associated with an increase in humans ALT submitted to prolonged treatment with zafirlukast.

The importance of assessing liver function in clinical safety tests is noteworthy, mainly because this organ is the most important site for metabolizing drugs and chemicals (El-Sayed et al., 2007). In addition, renal evaluation in clinical and toxicology studies has the same importance sincethis organ present significant excretory function in fish (Yildirim et al., 2006; Abdel-Daim et al., 2015).In this context, tilapia submitted to treatment with Zafirlukast for a prolonged period showed a reduction in creatinine values over time. These findings correspond to the results presented by Hagar et al. (2012) in which the anti-inflammatory action of zafirlukast significantly reduced the severity of acute ischemic renal failure in rats, resulting in a significant reduction in serum creatinine levels compared to untreated animals. According to Moraes et al. (2018), the reduction in plasma creatinine in mammals may be due to excessive diuresis. In freshwaterfish, this behavior can be explained by the osmoregulatory control mechanism, when these animals are in stress situations there is an imbalance in the ionic exchanges resulting in greater absorption of water from the environment (Takei et al., 2016) and the fish organism in an attempt to eliminate the liquid increases diuresis and consequently the elimination of creatinine. Therefore, it was possible to conclude that tilapia treated with $500 \mu \mathrm{g}$ ofzafirlukast showed attenuation of hematological changes resulting from fluid-electrolyte imbalance during a foreign bodyinflammation, as well as ameliorated serum biochemical disorders, demonstrating the clinical safety of oral treatment with this cys-leukotriene blocker.

\section{ACKNOWLEDGMENTS}

The authors would like to thank FAPESP-São Paulo Research Foundation (Process $n^{\circ}$ : 2016/23103-8) for the financial support needed to carry out this research.

\section{REFERENCES}

Abdel-Daim MM, Abdelkhalek NK, Hassan AM (2015). Antagonistic activity of dietary allicin against deltamethrin-induced oxidative damage in freshwater Nile tilapia; Oreochromis niloticus. Ecotoxicology and environmental safety. 111: 146-152.

Actis GC, Morgando A, Lagget M, David E, Rizzetto M (2001). Zafirlukast-related hepatitis: report of a further case. Journalofhepatology. 35: 539-541.

Aracati MF, Rodrigues LF, Oliveira SL, Moraes AC, Prado EJR, Fernandes DC, Eto, SF, Charlie-Silva I, Belo MAA (2021). Clinical safety of zafirlukast treatment during acute inflammatory reaction in Nile tilapia (Oreochromis niloticus), In press.

Belo MAA, Moraes FR, Yoshida L, Prado EJR, Moraes JRE, Soares VE, Silva MG (2014). Deleterious effects of low level of vitamin $\mathrm{E}$ and high stocking density on the hematology response of pacus, during chronic inflammatory reaction. Aquaculture. 422: 124128.

Belo MAA, Moraes JRED, Soares VE, Martins ML, Brum CD, Moraes FRD (2012a). Vitamin C and endogenous cortisol in foreign-body inflammatory response in pacus. Pesquisa Agropecuária Brasileira. 47: 1015-1021.

Belo MAA, Schalch SHC, Moraes FR, Soares VE, Otoboni AMMB, Moraes JER (2005). Effect of dietary supplementation with vitamin $\mathrm{E}$ and stocking density on macrophage recruitment and giant cell formation in the teleost fish, Piaractus mesopotamicus. Journal of Comparative Pathology. 133: 146154.

Belo MAA, Soares VE, Souza LM, Rosa Sobreira MF, Cassol DMS, Toma SB (2012b). Hepatoprotective treatment attenuates oxidative damages induced by carbon tetrachloride in rats. Experimental and toxicologic pathology. 64: 155-165.

Boyd CE (1990). Water quality in ponds for aquaculture. Alabama Agricultural Experiment 416 Station, Auburn University, AL, USA.

Carneiro PCF, Urbinati EC (2001). Salt as a stress response mitigator of matrinxã, Brycon cephalus (Günther), during transport. AquacultureResearch. 32: 297-304.

Charlie-Silva I, Conde G, Gomes JMM, Prado EJR, Fernandes DC, Moraes AC, Belo MADA (2020). Cyclophosphamide modulated the foreign body inflammatory reaction in tilapia (Oreochromis niloticus). Fish \& Shellfish Immunology. 107: 230-237.

Charlie-Silva I, Klein A, Gomes JM, Prado EJ, Moraes AC, Eto SF, Belo MA (2019). Acute-phase proteins during inflammatory reaction by bacterial infection: Fish-model. Scientific reports. 9: $1-13$.

El-Dessouki AM, El Fattah MA, Awad AS, Zaki HF (2018). Zafirlukast and vincamine ameliorate tamoxifen-induced oxidative stress and inflammation: Role of the JNK/ERK pathway. Life sciences. 202: 78-88.

El-Sayed YS, Saad TT, El-Bahr SM (2007). Acute intoxication of deltamethrin in monosex Nile tilapia, Oreochromis niloticus with special reference to the clinical, biochemical and haematological effects. Environmental Toxicology and Pharmacology. 24: 212217.

Fao (Food and Agriculture Organization of the United Nations) (2020) O Estado Mundial da Pesca e Aquicultura (SOFIA). Acessado: 19 de março de 2021.

Farias THV, Pereira NL, Pádua SBD, Alves LDO, Sakabe R, Belo MADA, Pilarski F (2016). Na2EDTA anticoagulant impaired blood samples from the teleost Piaractus mesopotamicus. Pesquisa Veterinária Brasileira. 36: 431-435. 
Forn-Cuní G, Varela M, Pereiro P, Novoa B, Figueras A (2017). Conserved gene regulation during acute inflammation between zebrafish and mammals. Scientific reports. 7: 1-9.

Hagar HH, Abd El Tawab R (2012). Cysteinyl leukotriene receptor antagonism alleviates renal injury induced by ischemiareperfusion in rats. Journal of surgical research. 178: e25-e34.

Hrubec TC, Cardinale JL, Smith SA (2000). Hematology and plasma chemistry reference intervals for cultured tilapia (Oreochromis hybrid). Veterinary clinical pathology. 29: 7-12.

Kim HJ, Yasuike M, Kondo H, Hirono I, Aoki T (2007). Molecular characterization and gene expression of a CXC chemokine gene from Japanese flounder Paralichthys olivaceus. Fish \& shellfish immunology. 23: 1275-1284.

Mahmoud S, Hasabelnaby S, Hammad S, Sakr T (2018). Antiviral nucleoside and nucleotide analogs: a review. Journal of Advanced Pharmacy Research. 2: 73-88.

Manrique WG, Figueiredo MA, Belo MADA, Martins ML, Moraes FR (2017). Inflamación crónica granulomatosa enel pez teleósteo Piaractusmesopotamicus: modelo de estudio histopatológico. Revista MVZ Córdoba. 22: 5738-5746.

Manrique WG, Silva-Claudiano G, Castro MP, Petrillo TR, Figueiredo MAP, Belo MADA, Moraes FR (2015). Expression of cellular components in granulomatous inflammatory response in Piaractus mesopotamicus model. PLoSOne. 10: e0121625.

Marcy TR, Britton ML, Blevins SM (2004). Second-generation thiazolidinediones and hepatotoxicity. Annals of Pharmacotherapy. 38: 1419-1423.

Mauel MJ, Miller DL, Merrill AL (2007). Hematologic and plasma biochemical values of healthy hybrid tilapia (Oreochromis aureus $\times$ Oreochromis nilotica) maintained in a recirculating system. Journal of zoo and wildlife medicine. 38: 420-424.

Mommsen TP, Vijayan MM, Moon TW (1999). Cortisol in teleosts: dynamics, mechanisms of action, and metabolic regulation. Reviews in Fish Biology and Fisheries. 9: 211-268.

Moraes AC, Prado EJR, Foz EP, Barbuio R, Faria VP, Belo MADA (2018). Hepatic steatosis alters cellular recruitment during induced aerocystitis in Nile tilapia. Pesquisa Veterinária Brasileira. 38: 1570-1576.

Natt MP, Herrick CA (1952). A new blood diluent for counting the erythrocytes and leucocytes of the chicken. Poultry Science. 31: 735-738.

Petrillo TR, Claudiano GS, Yunis-Aguinaga J, Manrique WG, Castro MP, Belo MADA, Moraes FR (2017). Influence of dexamethasone and levamisole on macrophage recruitment, giant cell formation and blood parameters in the tropical fish Piaractus mesopotamicus. Bioscience Journal. 33.
Prado EJR, Belo MAA, Moraes AC, Barbuio R, Foz EP, Faria VP, Sebastião FA (2018). Insulin favors acute inflammatory reaction in alloxan-diabetic tilapia during infectious aerocystitis. Pesquisa Veterinária Brasileira. 38: 2190-2193.

Reinus JF, Persky S, Burkiewicz JS, Quan D, Bass NM, Davern TJ (2000). Severe liver injury after treatment with the leukotriene receptor antagonist zafirlukast. Annalsofinternal medicine. 133. 964-968.

Rodrigues-Soares JP, Jesus GFA, Gonçalves ELT, Moraes KN, Chagas EC, Chaves FCM, Martins ML (2018). Induced aerocystitis and hemato-immunological parameters in Nile tilapia fed supplemented diet with essential oil of Lippia alba. Brazilian Journal of Veterinary Research and Animal Science. 55: 1-12.

Sakabe R, Moraes FRD, Belo MADA, Pilarski F, Moraes JRED (2013). Kinetics of chronic inflammation in Nile tilapia fed n-3 and n-6 essential fatty acids. Pesquisa Agropecuária Brasileira. 48: 313-319.

SAS Institute Inc. (2012) SAS/STAT software changes and enhancements through computer program. Release 9.3. Cary: SAS Institute.

Scheen, A. (2001). Thiazolidinediones and liver toxicity. Diabetes and Metabolism. 27: 305-13.

Scott JP, Peters-Golden M (2013). Antileukotriene agents for the treatment of lung disease. American journal of respiratory and critical care medicine. 188: 538-544.

Shih CC, Wu YW, Lin WC (2005). Aqueous extract of Anoectochilusformosanus attenuate hepatic fibrosis induced by carbon tetrachloride in rats. Phytomedicine, 12: 453-460.

Suja SR, Latha PG, Pushpangadan P, Rajasekharan S (2004). Evaluation of hepatoprotective effects of Helminthostachyszeylanica (L.) Hook against carbon tetrachloride-induced liver damage in Wistar rats. Journal of Ethnopharmacology. 92: 61-66.

Takei Y, Hwang PP (2016). Homeostatic responses to osmotic stress. In Fish Physiology (Vol. 35, pp. 207-249). Academic Press.

Wedemeyer G (1970). Stress of anesthesia with MS 222 and benzocaine in rainbow trout (Salmo gairdneri). Journal of the Fisheries Board of Canada. 27: 909-914.

Yildirim MZ, Benlı AÇK, Selvı M, Özkul A, Erkoç, F, Koçak O (2006). Acute toxicity, behavioral changes, and histopathological effects of deltamethrin on tissues (gills, liver, brain, spleen, kidney, muscle, skin) of Nile tilapia (Oreochromis niloticus L.) fingerlings. Environmental Toxicology: An International Journal. 21: 614-620. 